\title{
繰り返し曲げ変形を受ける同軸ケーブルの 芯線およびシールド線の寿命予測に関する研究
}

\author{
小粥 雅貴 ${ }^{* 1}$, 若松 栄史 ${ }^{* 2}$, 森永 英二*2 \\ 荒井 栄司 ${ }^{* 3}$, 島田 茂樹 ${ }^{* 4}$, 眞鍋 賢 ${ }^{* 5}$
}

\section{A study on life prediction of core and shielding wires contained in a coaxial cable bent cyclically}

\author{
Masataka OGAI ${ }^{* 1}$, Hidefumi WAKAMATSU ${ }^{* 2}$, Eiji MORINAGA ${ }^{* 2}$, Eiji ARAI $^{* 3}$, \\ Shigeki SHIMADA ${ }^{* 4}$ and Ken MANABE ${ }^{* 5}$ \\ ${ }^{*},{ }_{1,2},{ }^{*}$ Department of Materials and Manufacturing Science, Graduate School of Engineering, Osaka University \\ 2-1 Yamadaoka, Suita-shi, Osaka 565-0871, Japan \\ ${ }^{*},{ }^{*}$ Sumitomo Electric Industries, Ltd. \\ 1-1-3, Shimaya, Konohana-ku, Osaka 554-0024, Japan
}

Received 3 December 2013

\begin{abstract}
In this paper, a prediction method of the maximum principal strain of a core/shielding wire contained in a coaxial cable, which is related to the life-cycle of the wire, is proposed. If the central axis of a wire is assumed to be twisted around a virtual cylindrical surface when a coaxial cable is straight and a virtual toroidal surface when the cable is bent, the shape of the wire can be described by the first and the second fundamental form of their surfaces in the differential geometry. The potential energy of the wire, which is bent, twisted, expanded, and/or contracted, is also formulated based on the differential geometry. Friction of the wire against the virtual surface is modeled as a virtual spring in the circumferential direction of the surface and its elastic energy is included in the total potential energy of the wire. Then, the stable shape of the wire can be computed by minimizing its total potential energy under geometric constraints. After that, the maximum principal strain is estimated from the shape of the wire. As a result of simulation, it was founded that a core wire is broken by bending fatigue before the shielding wire is if they have the same radius and rigidity.
\end{abstract}

Key words : Life prediction, Coaxial cable, Core wire, Shielding wire, Differential geometry, Deformable linear object

\section{1. 緒言}

同軸ケーブルと呼ばれる電線は，信号を伝達する芯線に絶縁体を介して電磁波の漏洩を防止するためのシール ド線が巻き付いた構造をしており，非常に小さい精密機械や携帯電話などに用いられている。これらの電線は, 繰り返し曲げ変形を受けながら使用されることが多いが，その変形による電線の疲労がときに断線を引き起こす ことがある。そして，その断線までの寿命は，芯線とシールド線とが同じ材質および直径の場合，シールド線よ りも芯線の方が短いことが経験的に知られている，芯線が断線してしまうと，同軸ケーブルは製品としての機能 を失うため，その時点でシールド線が余寿命を持つことは無意味である，そのため，シールド線の材質を安価な ものに変えたり，直径を小さくし材料の使用量を減らすことで，芯線と同程度の寿命にすることができるのであ れば，コストの削減につながる，そのためには，芯線とシールド線の間にどの程度の寿命の違いがあるのかを予 測することが必要となる.繰り返し負荷を受ける材料の寿命は, ひずみの振幅と関係のあることが分かっている. よって, 寿命を予測するには, 同軸ケーブルの屈曲前後における芯線およびシールド線のひずみを求める必要が

No.13-00843 [DOI: 10.1299/transjsme.2014trans0141]

${ }^{* 1}$ 大阪大学大学院工学研究科 (广565-0871 大阪府吹田市山田丘 2-1)

$*_{2}$ 正員, 大阪大学大学院工学研究科

*3 正員, フェロー, 大阪大学大学院工学研究科

${ }^{* 4}$ 正員，住友電工(株）（广554-0024 大阪府大阪市此花区島屋 1-1-3）

*5 住友電工 (株)

E-mail of corresponding author: masataka.ogai@mapse.eng.osaka-u.ac.jp

[DOI: 10.1299/transjsme.2014trans0141] 
あり，これは各線の曲率およびねじれ率分布から導出することができる.

電線やワイヤロープの幾何形状や変形に対しては，これまで多くの研究がなされているが，電線やワイヤロー プは，細い線の束を多重に然り合わせるという構造の複雑さから，変形時における各束の曲率およびねじれ率分 布も含めた形状予測までを十分に取り扱っている例はまだない. 小野や Lee は微分幾何学を用いて電線の詳細な 幾何形状について考察を行っており, 線の束が一定のピッチで然られているとした場合に, その正確な形状や曲 率分布を求めることに成功している(Lee, 1987)(Lee, 1991)(小野，1993)(小野，2005). しかし，それはあくまでも 幾何的に導かれるものであり, 電線を屈曲させた場合に, 内部の束の配置がどのように変動するかといったこと は予測することができない. また, 清水やJun らは有限要素法を用いて電線内部構造の挙動評価を行っているが, 清水の研究においてはあくまでも曲げやせん断変形時に発生すると想定される強制変位を与えた場合の評価であ り，実際の変形を取り扱っているものではない(清水，2001).Jun らの研究はワイヤロープに対して軸力を作用 させた場合の評価であり，これも実際的な変形を考慮したものではない(Jun, et al., 2008).

電線・ワイヤロープにおける一般的な曲げ等を考慮した形状予測の例として，橋間らはワイヤハーネスの安定 形状を求めるためのリアルタイムシミュレーションを(橋間他，2007), 今西らはワイヤロープについて接触を考 慮した動的シミュレーションを行っている(Imanishi, et al., 2009). また，鈴木らはケーブルをばねと質点でモデル 化し，リアルタイムシミュレーションを行なっており(鈴木他，2005), Boyer らはキルヒホッフの梁理論を適用 し，有限要素法を用いて変形形状を予測している(Boyer, et al., 2011).しかし，これらの研究においては，電線・ ワイヤロープを一本の線状物体として取り扱っており，内部構造やその変化については考慮していない.

そこで本研究では，微分幾何学を用いて，同軸ケーブルにおける芯線およびシールド線の，曲率およびねじれ 率分布を含めた形状の導出を行う。モデルとしては，芯線およびシールド線に曲げおよびねじれ変形のみが生じ る場合と，伸縮も生じる場合，さらに，周囲の物体との間に摩擦が存在する場合も考える.また，芯線およびシ 一ルド線の然りピッチは一定ではないものとして, 静力学の変分原理により, 芯線およびシールド線の安定な電 線内配置を求める. 以上のようにして得られた形状からひずみ分布を求め, 芯線およびシールド線の寿命の違い について考察する.

\section{2. 伸縮と摩擦を考慮しない場合の素線束のモデリング}

\section{$2 \cdot 1$ 基本的な考え方}

図 1 に同軸ケーブルの断面の模式図を示す. 図中において濃く着色した芯線およびシールド線は，それぞれ異 なるピッチで然られている，㛜密には，それぞれの線は更に細い銅線を数十本束ねて撚り合わせたものとなって いるが, 本研究では, 図中の濃く着色された線（以下，素線束と呼ぶ）を密な弾性体と仮定し，それ以下の構造 は考えない. ケーブルの屈曲によって断面形状は変化しないものとすると, 素線束の中心軸は, 常に図中の仮想 曲面上に存在すると考えることができる. 仮想曲面は，ケーブルが無変形の場合には円筒面，ケーブルを一定曲 率で屈曲させた場合にはトーラス面となる.この仮想曲面上に，素線束中心軸が螺旋状に巻き付いているものと して定式化を行う。

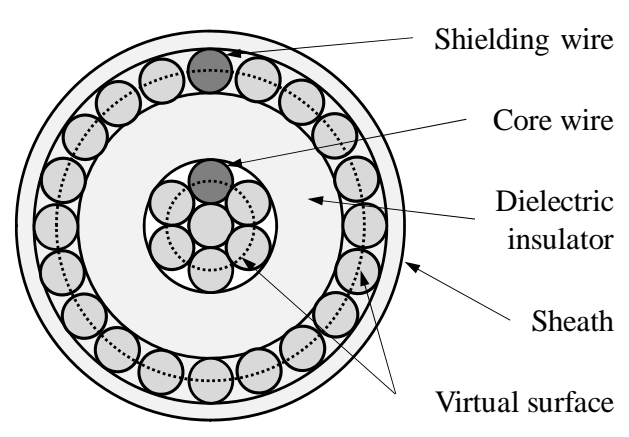

Fig. 1 The cross-section of a coaxial cable consisting of core wires, a dielectric insulator, shielding wires, and a sheath. A virtual surface is defined as a surface on which the central axis of a core/shielding wire is located. It corresponds to a cylindrical surface when the cable is straight and to a toroidal surface when the cable is bent circularly. 
素線束のモデル化には曲面の微分幾何を利用する. 曲面 $\boldsymbol{x}(u, v)$ 上にある点 $\mathrm{Q}(u, v)$ において, $u$ 方向列ベクトル を $\boldsymbol{x}_{u}(u, v), v$ 方向列ベクトルを $\boldsymbol{x}_{v}(u, v)$, 単位法線列ベクトルを $\boldsymbol{n}(u, v)$ とおき，これらを基底とする曲面座標系 $\mathrm{Q}(u, v)-u v w$ を設定する. ただし， $\boldsymbol{x}_{u}=\partial \boldsymbol{x} / \partial u, \boldsymbol{x}_{v}=\partial \boldsymbol{x} / \partial v$ であり，曲面は任意の点において $\boldsymbol{x}_{u}(u, v) \cdot \boldsymbol{x}_{v}(u, v)=0$ となるように定義されているものとする．この曲面上の曲線 $\boldsymbol{p}(u(t), v(t))$ について考える. ただし， $|d \boldsymbol{p} / d t|=1$ と する. このとき，曲線の法曲率 $\kappa_{e}$ と測地的㧖率 $T$ は，曲面の第一基本量 $E, F, G$ および第二基本量 $L, M$, $N$ (小林，1995)を用いて以下のように表される(小野，2005).

$$
\left\{\begin{array}{l}
\kappa_{e}=L \frac{d u}{d t} \frac{d u}{d t}+2 M \frac{d u}{d t} \frac{d v}{d t}+N \frac{d v}{d t} \frac{d v}{d t}, \\
T=\frac{1}{\sqrt{E G-F^{2}}}\left\{(E M-F L) \frac{d u}{d t} \frac{d u}{d t}+(E N-G L) \frac{d u}{d t} \frac{d v}{d t}+(F N-G M) \frac{d v}{d t} \frac{d v}{d t}\right\}
\end{array}\right.
$$

なお，曲線の測地的曲率 $\kappa_{g}$ にいては，小野の定義式では極めて複雑となるため，別途考える.

一方, 素線束中心軸の長さを $l$ とし, 中心軸左端から中心軸に沿った距離を $s$ とする. 素線束中心軸上の点 $\mathrm{P}(s)$ において, 中心軸方向に $\zeta$ 軸が一致するように物体座標系 $\mathrm{P}(s)-\xi \eta \zeta$ を設定する. この座標系の各軸方向単位列 ベクトルを $\xi(s), \eta(s), \zeta(s)$ とおく.ここで, $\xi(s), \eta(s), \zeta(s)$ の に関する微分は, 剛体の角速度との類似 性から以下のように表すことができる.

$$
\frac{\mathrm{d}}{\mathrm{d} s}\left[\begin{array}{lll}
\xi & \eta & \zeta
\end{array}\right]=\left[\begin{array}{lll}
\xi & \eta & \zeta
\end{array}\right]\left[\begin{array}{ccc}
0 & -\omega_{\zeta} & \omega_{\eta} \\
\omega_{\zeta} & 0 & -\omega_{\xi} \\
-\omega_{\eta} & \omega_{\xi} & 0
\end{array}\right]
$$

ここで， $\omega_{\xi}(s), \omega_{\eta}(s), \omega_{\zeta}(s)$ を各軸回りの回転率と呼ぶことにする. なお， $\omega_{\xi}(s)$ は $\xi$ 軸回りの曲率， $\omega_{\eta}(s)$ は $\eta$ 軸回りの曲率， $\omega_{\zeta}(s)$ は $\zeta$ 軸回りの㸚じれ率に相当する.

$d \boldsymbol{p} / d t=\boldsymbol{\zeta}$ となるように曲面上の点 $\mathrm{Q}(u, v)$ と素線束中心軸上の点 $\mathrm{P}(s)$ とを重ね, 点 $\mathrm{P}(s)$ の近傍において, 素線 束中心軸と曲面 $\boldsymbol{x}(u, v)$ 上の曲線 $\boldsymbol{p}(u(t), v(t))$ とを一致させたとする．このとき， $d t=d s$ であり, $\boldsymbol{n}=\boldsymbol{\eta}$ であるとす ると，

$$
\kappa_{e}=-\omega_{\xi}, \quad \kappa_{g}=\omega_{\eta}, \quad T=\omega_{\zeta}
$$

となる．したがって，ある曲面に巻き付けられた素線束中心軸の曲率およびねじれ率は，曲面の基本量を用いて 表すことができる，なお，以降では，法曲率を生じる素線束中心軸の変形を面外変形と呼び，その時の曲率を $\omega_{0}$ と表す．また，測地的曲率を生じる変形を面内変形と呼び，その時の曲率を $\omega_{i}$ と表す，以上を踏まえて，次節で は，素線束が伸縮しない場合についてモデル化を行う.

\section{$2 \cdot 2$ 初期状態における素線束の形状表現}

同軸ケーブルが初期状態，すなわち無変形状態の場合には，素線束の中心軸は仮想円筒面に螺旋状に巻き付け られていると考えることができる．ここで，半径 $r$ の円筒面の第一基本量および第二基本量について考える. 円 筒の軸方向に $u$ 軸を, 円周方向に $v$ 軸を, 外向き法線方向に $w$ 軸をとる. 円筒面の方程式を

$$
\boldsymbol{x}(u, v)=\left[\begin{array}{c}
u \\
r \sin v \\
r \cos v
\end{array}\right]
$$

とすると, 座標系 $\mathrm{Q}(u, v)$ - $u v w$ における第一基本量は $E=1, F=0, G=r^{2}$, 第二基本量は $L=0, M=0, N=-r$ となる.この時, $u$ 方向ベクトル $\boldsymbol{x}_{u}(u, v)$ と円筒上の曲線 $\boldsymbol{p}(u(t), v(t))$ の接線ベクトル $d \boldsymbol{p} / d t$ とのなす角が $\alpha$ で与え られるとすると, $\cos \alpha d t=d u, \sin \alpha d t=r d v$ となり, 曲線の法曲率 $\kappa_{e}$ と測地的㧖率 $T$ は, 式(1)より 


$$
\kappa_{e}=-\frac{1}{r} \sin ^{2} \alpha, \quad T=-\frac{1}{r} \sin \alpha \cos \alpha
$$

と表せる.

以上を踏まえ，まず，この円筒の中心軸方向から角度 $\alpha$ だけ傾けて，帯状物体を螺旋状に巻き付けることを考 える. 帯の中心軸方向が $\zeta$ 軸に, 帯の法線方向が $\eta$ 軸に一致するように物体座標系を設定すると, 帯上の各点に おける回転率 $\omega_{\xi}$ および $\omega_{\zeta}$ は

$$
\omega_{\xi}=-\kappa_{e}=\frac{1}{r} \sin ^{2} \alpha, \quad \omega_{\zeta}=T=-\frac{1}{r} \sin \alpha \cos \alpha
$$

を満たす必要がある，つまり，帯を円筒面から離れないように巻き付ける，特に帯の法線方向ベクトル $\boldsymbol{\eta}$ が常に 円筒面の外向き法線ベクトル $\boldsymbol{n}$ と一致するように巻き付けるためには，上式のような回転率，特にねじれ率 $\omega_{\zeta} に$ 関する制約を満たす必要がある。

素線束の場合，円筒に巻き付けるのとは独立に，自身もねじれている場合がある．この時，素線束中心軸に設

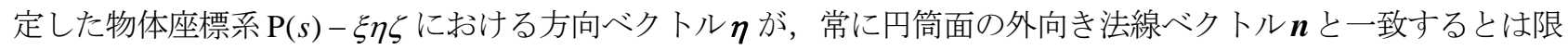
らない.つまり,

$$
\omega_{\zeta}=T+\Delta \omega
$$

となる場合，素線束が仮想円筒面の周りに巻き付くことを公転ねじれ，素線束自体がねじれることを自転ねじれ と呼ぶことにすると，T が公転ねじれに関係するねじれを， $\Delta \omega$ が自転ねじれを表していることになる。そこで， 円筒面の外向き法線ベクトル $\boldsymbol{n}$ と素線束中心軸の $\boldsymbol{\eta}$ ベクトルとのなす角 $\beta(s)$ を導入しておく.

前述の円筒に，図 2 のように，円筒中心軸から角度 $\alpha$ だけ傾けて，素線束中心軸を螺旋状に巻き付けることを 考える. 図において，円筒面上の座標系各軸方向を $\boldsymbol{x}_{u}, \boldsymbol{x}_{v}, \boldsymbol{n}$ で，素線中心軸上の座標系各軸方向を $\boldsymbol{\xi}, \boldsymbol{\eta}, \boldsymbol{\zeta}$ で表している，面外曲げ変形 $\omega_{o}$, 面内曲げ変形 $\omega_{i}$ は回転率 $\omega_{\xi}$ および $\omega_{\eta}$ の接平面に垂直および水平な成分と考 えることができるので，図より，それぞれ以下のように表せる.

$$
\omega_{o}=\omega_{\xi} \cos \beta+\omega_{\eta} \sin \beta, \quad \omega_{i}=-\omega_{\xi} \sin \beta+\omega_{\eta} \cos \beta
$$

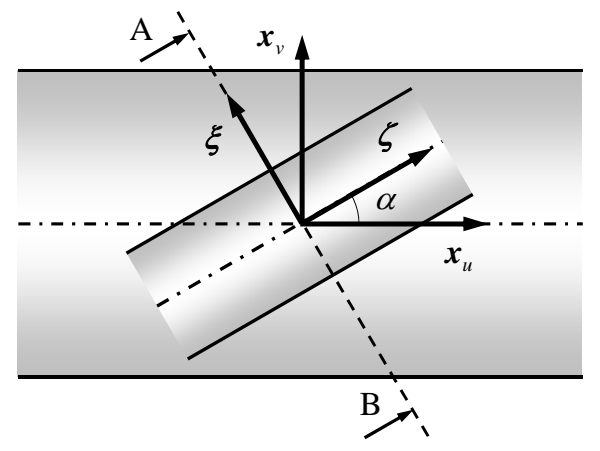

(a) Definition of $\alpha$

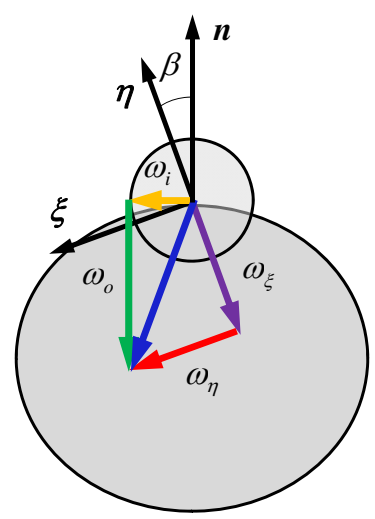

(b) Cross-section at plane $\mathrm{AB}$ and definition of $\beta$

Fig. 2 Twining of a strand around a virtual cylindrical surface. The pitch angle $\alpha$ and the torsional angle $\beta$ determine how the strand twines around the virtual cylindrical surface. The principal curvature, which corresponds to the resultant of the rotational ratio around the $\xi$ axis $\omega_{\xi}$ and that around the $\eta$ axis $\omega_{\eta}$, can be decomposed to the in-plane curvature $\omega_{i}$ and the out-of-plane curvature $\omega_{0}$. 
一方, 面外曲げ変形および面内曲げ変形は以下の制約を満たす必要がある.

$$
\omega_{o}=-\kappa_{e}, \quad \omega_{i}=\frac{d \alpha}{d s}
$$

更に，素線束のねじれに関して，式(7)における $\Delta \omega$ は-d $\beta / \mathrm{d} s$ で与えられるので， $\omega_{\xi}(s) ， \omega_{\eta}(s), \omega_{\zeta}(s)$ は，変 数 $\alpha(s)$ および $\beta(s)$ を用いて,

$$
\omega_{\xi}=\frac{1}{r} \sin ^{2} \alpha \cos \beta-\frac{d \alpha}{d s} \sin \beta, \quad \omega_{\eta}=\frac{1}{r} \sin ^{2} \alpha \sin \beta+\frac{d \alpha}{d s} \cos \beta, \quad \omega_{\zeta}=-\frac{1}{r} \sin \alpha \cos \alpha-\frac{d \beta}{d s}
$$

と表すことができる.

素線束中心軸上の点 $\mathrm{P}(s)$ における中心軸方向 $\zeta(s)$ は, 左端での各軸方向 $\boldsymbol{\xi}(0), \boldsymbol{\eta}(0), \boldsymbol{\zeta}(0)$ と各点での各軸回 りの回転率 $\omega_{\xi}(s), \omega_{\eta}(s), \omega_{\zeta}(s)$ が分かれば, 式(2)の微分方程式よりルンゲ・クッタ法などを用いて数值的に 求めることができる. さらに, 素線束中心軸上の点 $\mathrm{P}(s)$ の空間座標を $\boldsymbol{x}(s)=[x(s), y(s), z(s)]^{\mathrm{T}}$ とおくと,

$$
\boldsymbol{x}(s)=\boldsymbol{x}_{0}+\int_{0}^{s} \zeta(s) d s
$$

と表すことができる.ここで $\boldsymbol{x}_{0}=\left[x_{0}, y_{0}, z_{0}\right]^{\mathrm{T}}$ を素線束中心軸左端の空間座標とする. したがって, 素線束中心軸 の形状は, 2 変数 $\alpha(s)$ および $\beta(s)$ を用いて表現することができる. 本研究では, 前者を撚りピッチ角, 後者をね じり角と呼ぶ.

\section{$2 \cdot 3$ 初期状態における素線束のポテンシャルエネルギーと制約条件の定式化}

素線束の変形によるポテンシャルエネルギーU $U$ は, 各軸回りの回転率 $\omega_{\xi}(s), \omega_{\eta}(s), \omega_{\zeta}(s)$ を用いて

$$
U=\frac{R_{f}}{2} \int_{0}^{l}\left(\omega_{\eta}^{2}+\omega_{\xi}^{2}\right) d s+\frac{R_{t}}{2} \int_{0}^{l} \omega_{\zeta}^{2} d s
$$

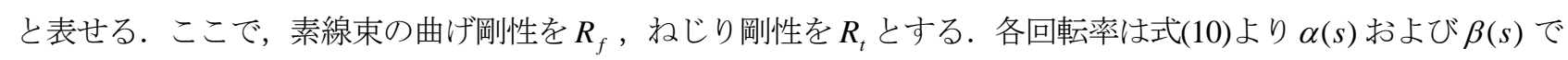
表されるため, 結局, 素線束のポテンシャルエネルギーUは $\alpha(s)$ および $\beta(s)$ を用いて表現することができる. また，素線束が長さ $l$ の間に $N_{g}$ 回転撚られ，それとは別に $N_{l}$ 回転㸚じられている場合には

$$
\int_{0}^{l} \sin \alpha d s=2 \pi r N_{g}, \quad \beta(l)-\beta(0)=2 \pi N_{l}
$$

のような $\alpha(s)$ および $\beta(s)$ に対する制約が加えられる.よって, 式(13)のような制約条件のもとで，ポテンシャル エネルギーUが最小となるような 2 変数 $\alpha(s)$ および $\beta(s)$ を求めることにより, 初期状態における素線束の形状 を導出できる.

\section{2 -4 素線束の初期形状の導出手法}

本研究では, Ritz 法(Elsgolc, 1961)と非線形計画法をもとに素線束の形状を求める.まず， $\alpha(s)$ および $\beta(s)$ を 基底関数 $e_{1}(s), \cdots, e_{n}(s)$ の線形和で表す.

$$
\alpha(s)=\sum_{i=1}^{n} a_{i}^{\alpha} e_{i}(s)=\boldsymbol{a}^{\alpha} \cdot \boldsymbol{e}(s), \quad \beta(s)=\sum_{i=1}^{n} a_{i}^{\beta} e_{i}(s)=\boldsymbol{a}^{\beta} \cdot \boldsymbol{e}(s)
$$

ここで， $\boldsymbol{a}^{\alpha}$ およ゙ $\boldsymbol{a}^{\beta}$ は係数ベクトルである.さらにこれらをまとめてべクトル $\boldsymbol{a}$ で表すと，素線束の形状は， 式(13)のような制約条件のもとで, 式(12)を最小にするような係数ベクトル $\boldsymbol{a}$ を計算することにより求めることが できる，これは，制約つき最適化問題であり，非線形計画問題の解法を用いて数值的に解くことができる. 
同軸ケーブルの素線束の場合, 初期状態では一定の撚りピッチ角 $\alpha_{0}$ で撚られているため $\alpha(s)=\alpha_{0}$ となり, 初 期状態における自転ねじれは 0 であるので $\beta(s)=0$ となる. よって, 回転率は式(10)より一意に定まる. こうし て求められた回転率を初期回転率 $\omega_{\xi 0}(s), \omega_{\eta 0}(s), \omega_{\zeta 0}(s)$ とする.

\section{$2 \cdot 5$ 屈曲状態での素線束の変形形状の導出手法}

次に，同軸ケーブルの曲げ変形について考える．同軸ケーブルの外側はシースで覆われているため，同軸ケー ブル中心軸を一定の曲率 $1 / R$ で曲げた場合, 同軸ケーブル中心軸から各素線束中心軸までの距離は変化しないも のと仮定する. すると，曲げ変形後の各素線束の中心軸は，仮想トーラス面の上に螺旋状に巻き付いていると考 えられる. ただし, 螺旋のピッチ角は場所によって変化し得る. ここで, 仮想トーラス面を以下のように表す.

$$
\boldsymbol{x}(u, v)=\left[\begin{array}{c}
(R+r \cos v) \cos u \\
(R+r \cos v) \sin u \\
r \sin v
\end{array}\right]
$$

この時, 第一基本量は $E=(R+r \cos v)^{2}, F=0, G=r^{2}$, 第二基本量は $L=-(R+r \cos v) \cos v, M=0, N=-r$ となる.ここで,

$$
v=\frac{1}{r} \int_{0}^{s} \sin \alpha \mathrm{d} s
$$

となる. $u$ 方向ベクトル $\boldsymbol{x}_{u}(u, v)$ とトーラス面上の曲線 $\boldsymbol{p}(u(t), v(t))$ の接線ベクトル $d \boldsymbol{p} / d t$ とのなす角が $\alpha$ で与えら れるとすると, $\cos \alpha d t=(R+r \cos v) d u, \sin \alpha d t=r d v$ となり, 曲線の法曲率 $\kappa_{e}$ と測地的㧖率 $T$ は, 式(1)より

$$
\left\{\begin{array}{l}
\kappa_{e}=-\frac{\cos v}{R+r \cos v} \cos ^{2} \alpha-\frac{1}{r} \sin ^{2} \alpha, \\
T=\frac{\cos v}{R+r \cos v} \cos \alpha \sin \alpha-\frac{1}{r} \sin \alpha \cos \alpha
\end{array}\right.
$$

と表せる. よって, トーラス面の $u$ 軸方向から角度 $\alpha$ だけ傾けて, 素線束中心軸を螺旋状に巻き付けた場合, 面 外曲げ変形曲率 $\omega_{o}$ は $\omega_{o}=-\kappa_{e}$ となる.

次に面内変形 $\omega_{i}$ について考える. トーラス面上に設定した $u$ 軸に対して接線が平行となる円環は緯線, $v$ 軸に 対して接線が平行となる円環は経線と呼ばれる. 緯線はトーラス中心軸にも平行な曲線である. また, 緯線の主 曲率は $1 /(R+r \cos v)$ で与えられる．そこで， $w$ 軸から見たときの緯線の向きの微小変化量を $\mathrm{d} \phi$ とおくと，

$$
\mathrm{d} \phi=\frac{\sin v}{R+r \cos v} \mathrm{~d} \delta
$$

となる.ここで, $\mathrm{d} \delta$ は緯線に沿った微小長さとする. ピッチ角 $\alpha$ は $u$ 軸に対して定義されるため, ピッチ角自 体も $\mathrm{d} \alpha$ だけ変化すると, $w$ 軸から見たときの素線束中心軸の向きの微小変化量 $\mathrm{d} \theta$ は

$$
\mathrm{d} \theta=\frac{\sin v}{R+r \cos v} \mathrm{~d} \delta+\mathrm{d} \alpha
$$

となる．素線束の微小長さ $\mathrm{d} s$ で考えると， $\mathrm{d} \delta=\cos \alpha \mathrm{d} s$ であるため，結局，面内曲率 $\omega_{i}$ は

$$
\omega_{i}=\frac{\mathrm{d} \theta}{\mathrm{d} s}=\frac{\sin v}{R+r \cos v} \cos \alpha+\frac{\mathrm{d} \alpha}{\mathrm{d} s}
$$

となる，一方，トーラス面への巻き付けであっても式(8)が成り立つので, 


$$
\omega_{\xi} \cos \beta+\omega_{\eta} \sin \beta=-\kappa_{e}, \quad-\omega_{\xi} \sin \beta+\omega_{\eta} \cos \beta=\frac{\sin v}{R+r \cos v} \cos \alpha+\frac{\mathrm{d} \alpha}{\mathrm{d} s}
$$

となる．更に，中心軸のねじれ率は，測地的㧖率を用いて

$$
\omega_{\zeta}=T+\frac{\mathrm{d} \beta}{\mathrm{d} s}
$$

と表せる，上式より $\omega_{\xi}(s) ， \omega_{\eta}(s) ， \omega_{\zeta}(s)$ は変数 $\alpha(s)$ および $\beta(s)$ を用いて，

$$
\left\{\begin{array}{l}
\omega_{\xi}=\frac{\cos v}{R+r \cos v} \cos ^{2} \alpha \cos \beta+\frac{1}{r} \sin ^{2} \alpha \cos \beta-\frac{\sin v}{R+r \cos v} \cos \alpha \sin \beta-\frac{\mathrm{d} \alpha}{\mathrm{d} s} \sin \beta \\
\omega_{\eta}=\frac{\cos v}{R+r \cos v} \cos ^{2} \alpha \sin \beta+\frac{1}{r} \sin ^{2} \alpha \sin \beta+\frac{\sin v}{R+r \cos v} \cos \alpha \cos \beta+\frac{\mathrm{d} \alpha}{\mathrm{d} s} \cos \beta \\
\omega_{\zeta}=\frac{\cos v}{R+r \cos v} \cos \alpha \sin \alpha-\frac{1}{r} \sin \alpha \cos \alpha-\frac{\mathrm{d} \beta}{\mathrm{d} s}
\end{array}\right.
$$

\section{と表すことができる.}

素線束中心軸上の点 $\mathrm{P}(s)$ における中心軸方向ベクトル $\zeta(s)$ は，初期状態の場合の素線束と同様に，式(2)より ルンゲ・クッタ法等の逐次計算を用いて導出でき, また, 点 $\mathrm{P}(s)$ の空間座標は式(11)で表すことができる.した がって，屈曲状態における素線束中心軸の形状も， 2 変数 $\alpha(s)$ および $\beta(s)$ を用いて表現することができる.

次に，屈曲状態における素線束のポテンシャルエネルギーUは，初期状態でのポテンシャルエネルギーを 0 と して，近似的に以下のように表すことができる.

$$
U=\frac{R_{f}}{2} \int_{0}^{l}\left\{\left(\omega_{\xi}-\omega_{\xi 0}\right)^{2}+\left(\omega_{\eta}-\omega_{\eta 0}\right)^{2}\right\} \mathrm{d} s+\frac{R_{t}}{2} \int_{0}^{l}\left(\omega_{\zeta}-\omega_{\zeta 0}\right)^{2} \mathrm{~d} s
$$

よって, 式(13)のような制約条件の下で, 式(24)で表されるポテンシャルエネルギーUが最小となるような 2 変数 $\alpha(s)$ および $\beta(s)$ を求めることにより, 屈曲状態における素線束の変形形状を導出できる. 図 3 に, 屈曲状態の 同軸ケーブルにおける素線束の変形形状の計算例を示す.

\section{$2 \cdot 6$ 主ひずみの導出と寿命の推定}

初期状態から屈曲状態に変化した場合の回転率の増分を $\Delta \omega_{\xi}=\omega_{\xi}-\omega_{\xi_{0}}, \Delta \omega_{\eta}=\omega_{\eta}-\omega_{\eta_{0}}, \Delta \omega_{\zeta}=\omega_{\zeta}-\omega_{\zeta_{0}}$ と おく，変形によって素線束に発生するひずみは，素線束表面の主曲率方向にある点で最大となり，素線束表面に おいて平面ひずみ状態を仮定すると，主ひずみ $\varepsilon_{1}, \varepsilon_{2}$ は

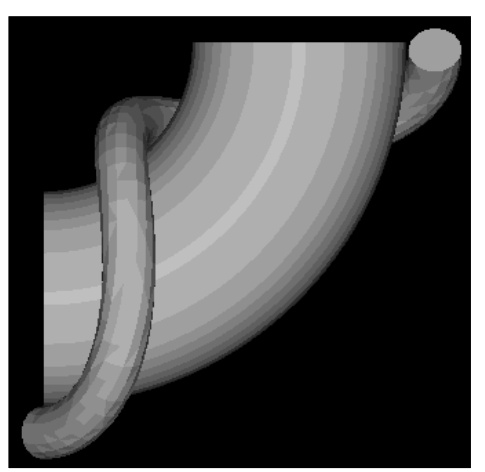

Fig. 3 An example of the deformed shape of a strand contained in a coaxial cable bent circularly. 


$$
\varepsilon_{1}, \varepsilon_{2}=\frac{\rho \sqrt{\left(\Delta \omega_{\xi}\right)^{2}+\left(\Delta \omega_{\eta}\right)^{2}}}{2} \pm \frac{\rho}{2} \sqrt{\left(\Delta \omega_{\xi}\right)^{2}+\left(\Delta \omega_{\eta}\right)^{2}+\left(\Delta \omega_{\zeta}\right)^{2}}
$$

となる．ここで，素線束の半径を $\rho$ とする．素線束の変形形状が求まれば，素線束の回転率分布から，上式を用 いて素線束の主ひずみ分布を求めることができる，ひずみと寿命の関係は，以下に示すバスキンの法則によって 定式化されている.

$$
N=A \Delta \varepsilon^{-B}
$$

ここで， $N$ は破断に至るまでの繰り返し数， $\Delta \varepsilon$ はひずみの振幅， $A$ と B は材料や使用環境条件等によって変わ る係数を表す，式(25)で表される主ひずみは，初期状態から屈曲状態へと変化した場合のひずみの増分と考える ことができるので，式(25)と式(26)より，素線束の寿命を推定することができる.

\section{3. 伸縮と摩擦を考慮した場合の素線束のモデリング}

\section{$3 \cdot 1$ 伸縮と摩擦の考慮の必要性}

前章において，素線束中心軸は曲げ変形を受けた後でも伸縮は発生しないものとして変形形状を導出した。し かし，実際の素線束中心軸では伸縮が発生している可能性があるため，本章においては素線束中心軸の伸縮を考 慮した変形形状の導出を行う。また，ケーブルの屈曲により撚りピッチ角 $\alpha(s)$ が初期状態から変化した場合, 式 (16)より，素線束は仮想トーラス面を経線方向に移動することになる．素線束と仮想トーラス面との間に摩擦が なければ，素線束のポテンシャルエネルギーが最小となる位置まで移動することが可能であるが，実際には，芯 線はケーブル中心の素線束および外側の絶縁体と，シールド線は内側の絶縁体および外側のシースと接触してい るため, 摩擦により十分に滑りを生じない可能性がある.よって, 本章では素線の摩擦も考慮した変形形状の導 出を行う。

\section{$3 \cdot 2$ 伸縮のモデリング}

変形により, 素線束中心軸上の点 $\mathrm{P}(s)$ における微小長さ $\mathrm{d} s$ が $(1+\varepsilon) \mathrm{d} s$ に変化したとする. ここで, $\varepsilon(s)$ を点 $\mathrm{P}(s)$ における素線束の中心軸方向の垂直ひずみとする．素線束の回転率は微小長さ $d s$ に対して定義されるもの であるので，この時，例えば $\xi$ 軸回りのみかけの回転率は $\omega_{\xi} /(1+\varepsilon)$ となる.よって，式(25)は伸縮を考慮した場 合，以下のようになる.

$$
\left\{\begin{array}{l}
\omega_{\xi}=(1+\varepsilon)\left(\frac{\cos v}{R+r \cos v} \cos ^{2} \alpha \cos \beta+\frac{1}{r} \sin ^{2} \alpha \cos \beta-\frac{\sin v}{R+r \cos v} \cos \alpha \sin \beta\right)-\frac{\mathrm{d} \alpha}{\mathrm{d} s} \sin \beta \\
\omega_{\eta}=(1+\varepsilon)\left(\frac{\cos v}{R+r \cos v} \cos ^{2} \alpha \sin \beta+\frac{1}{r} \sin ^{2} \alpha \sin \beta+\frac{\sin v}{R+r \cos v} \cos \alpha \cos \beta\right)+\frac{\mathrm{d} \alpha}{\mathrm{d} s} \cos \beta \\
\omega_{\zeta}=(1+\varepsilon)\left(\frac{\cos v}{R+r \cos v} \cos \alpha \sin \alpha-\frac{1}{r} \sin \alpha \cos \alpha\right)-\frac{\mathrm{d} \beta}{\mathrm{d} s}
\end{array}\right.
$$

ここで,

$$
v=\frac{1}{r} \int_{0}^{s}(1+\varepsilon) \sin \alpha \mathrm{d} s
$$

とする．よって，式(24)において式(27)の各回転率を用いることにより，素線束の伸縮を考慮できる. 


\section{$3 \cdot 3$ 摩擦のモデリング}

素線の撚りピッチ角が $\alpha_{0}(s)$ から $\alpha(s)$ に変化した場合, ある点 $\mathrm{P}(s)$ での仮想トーラス面における経線方向の移 動距離 $\Delta c$ は

$$
\Delta c=\int_{0}^{s}(1+\varepsilon) \sin \alpha \mathrm{d} s-\int_{0}^{s} \sin \alpha_{0} \mathrm{~d} s=\int_{0}^{s}(1+\varepsilon) \sin \alpha \mathrm{d} s-c_{0}(s)
$$

となる. 本研究においては，この滑り現象を仮想ばねを用いて簡易的にモデル化する. すなわち，初期状態にお ける点 $\mathrm{P}(s)$ の経線方向の位置 $c_{0}(s)$ において自然長となる, ばね定数 $k$ の経線方向に平行な仮想的なばねを考え る．ケーブルの屈曲により式(29)のような変位が生じた場合，仮想ばねには

$$
U_{k}=\frac{1}{2} k(\Delta c)^{2}
$$

なるエネルギーが発生すると仮定する，上式のばね定数 $k$ の大きさにより，素線の滑りやすさを表現することが できる.

\section{$3 \cdot 4$ 伸縮と摩擦を考慮した形状と主ひずみの導出}

素線束の伸縮および摩擦を考慮したポテンシャルエネルギーは以下のように表すことができる.

$$
U=\frac{R_{e}}{2} \int_{0}^{l} \varepsilon^{2} \mathrm{~d} s+\frac{R_{f}}{2} \int_{0}^{l}\left\{\left(\omega_{\xi}-\omega_{\xi 0}\right)^{2}+\left(\omega_{\eta}-\omega_{\eta 0}\right)^{2}\right\} \mathrm{d} s+\frac{R_{t}}{2} \int_{0}^{l}\left(\omega_{\zeta}-\omega_{\zeta 0}\right)^{2} \mathrm{~d} s+\frac{k}{2} \int_{0}^{l}(\Delta c)^{2} \mathrm{~d} s
$$

ここで， $R_{e}$ を素線束の伸び岡性とする．なお，垂直ひずみ $\varepsilon(s)$ は未知数であるため，式(14)と同様に基底関数の 線形和で表し, $\varepsilon(s)$ に関寸る係数 $\boldsymbol{a}^{\varepsilon}$ を含めた係数 $\boldsymbol{a}$ に対して最適化計算を行うことで, 伸縮と摩擦を考慮した素 線束の形状を導出できる.この時，主ひずみは

$$
\Delta \kappa=\sqrt{\left(\Delta \omega_{\xi}\right)^{2}+\left(\Delta \omega_{\eta}\right)^{2}}
$$

とおくと，

$$
\varepsilon_{1}, \varepsilon_{2}=\frac{\varepsilon+\rho \Delta \kappa}{2} \pm \frac{1}{2} \sqrt{(\varepsilon+\rho \Delta \kappa)^{2}+\left(\rho \Delta \omega_{\zeta}\right)^{2}}
$$

となる．よって，式(33)と式(26)より，伸縮と摩擦を考慮した場合の素線束の寿命を推定することができる.

\section{4. ケーススタディ}

\section{$4 \cdot 1$ 伸縮と摩擦を考慮しない場合の主ひずみの推定}

前章まで述べてきた素線束の変形形状導出手法を, 実際の同軸ケーブルに適用して主ひずみを推定する. 対象 とする同軸ケーブルの芯線およびシールド線の物性值を表 1 に示す．なお，以降の計算では，以下に示すような 基底関数を用いる.

$$
e_{1}(s)=1, \quad e_{2}(s)=s, \quad e_{2 i+1}(s)=\sin \frac{i \pi s}{l}, \quad e_{2 i+2}(s)=\cos \frac{i \pi s}{l} \quad(i=1, \cdots, 9)
$$

まず，伸縮と摩擦を考慮しない場合について考察する．同軸ケーブルを屈曲させた場合の芯線およびシールド 線の撚りピッチ角 $\alpha(s)$ を図 4 に, 㸚じり角 $\beta(s)$ を図 5 に示寸. 図 4 および図 5 より, 初期状態において一定だ った撚りピッチ角およびねじり角が，ケーブルが屈曲することにより, 芯線, シールド線共に不均一な分布に変 化していることが分かる. 屈曲時の撚りピッチ角は, $s=l / 2$, すなわち屈曲部の最内周で最大となり, $s=0 お$ よび $s=l$, すなわち屈曲部の最外周で最小となっている. 屈曲部の内周ではケーブル軸方向への圧縮力, 外周で 
は引張力がはたらくため, 内周では撚りピッチ角が増加することでケーブル軸方向への距離が減少し，外周では 撚りピッチ角が減少することでケーブル軸方向への距離が増加しているものと考えられる. このように, 本提案 手法では，同軸ケーブルの変形による撚りピッチ角およびねじり角の変化を表現することができる．次に，同軸 ケーブルを屈曲させた場合の芯線およびシールド線の最大主ひずみ $\varepsilon_{1}(s)$ を図 6 に示す. 図 6 より, 最大主ひずみ はシールド線より芯線の方が大きい部分があることが分かる. 式(26)より, 最大主ひずみの大きい部分は小さい 部分に比較して寿命が短くなるため, 本提案手法により, 芯線の方がシールド線より寿命が短いと推定でき, こ れは現実と矛盾しない，また，最大主ひずみが最大となる部分は屈曲部の最内周ではなく，側面に近い部分であ り，これは，繰り返し曲げ変形を受けた同軸ケーブルの芯線の実際の破断位置とも一致している．以上のことか ら, 本提案手法は, 同軸ケーブルの芯線およびシールド線の寿命を推定する手法として妥当であると考えられる.

\section{$4 \cdot 2$ 伸縮と摩擦を考慮した場合の主ひずみの推定}

次に，伸縮と摩擦を考慮した場合について考察する．芯線およびシールド線の物性值は表 1 に示したものと同 様とし，表 2 のうに，伸び岡性 $R_{e}$ および仮想ばねのばね定数 $k$ を変化させた場合の最大主ひずみ $\varepsilon_{1}(s)$ を求め る.

Table 1 Parameters of core/shielding wire

\begin{tabular}{|c|c|c|}
\hline Kind of the wire & Core wire & Shielding wire \\
\hline Ratio of the torsional rigidity to the flexural rigidity $: R_{t} / R_{f}$ & \multicolumn{2}{|c|}{0.77} \\
\hline Radius of the wire $: \rho[\mathrm{mm}]$ & \multicolumn{2}{|c|}{$1.50 \times 10^{-2}$} \\
\hline Length of the cable $[\mathrm{mm}]$ & 1.00 & 5.00 \\
\hline Length of the wire $: l[\mathrm{~mm}]$ & 1.02 & 5.04 \\
\hline Radius of the virtual cylinder/Minor radius of the virtual torus $: r[\mathrm{~mm}]$ & $3.00 \times 10^{-2}$ & $1.05 \times 10^{-1}$ \\
\hline Major radius of the virtual torus (Radius of curvature for bending) $: R[\mathrm{~mm}]$ & \multicolumn{2}{|c|}{3.00} \\
\hline Global rotation $: N_{g}$ & 1.00 \\
\hline Local rotation $: N_{l}$ & 0.00 \\
\hline Initial pitch angle $: \alpha_{0}[\mathrm{rad}]$ & $1.86 \times 10^{-1}$ & $1.31 \times 10^{-1}$ \\
\hline Initial torsional angle $: \beta_{0}[\mathrm{rad}]$ & \multicolumn{2}{|c|}{0.00} \\
\hline
\end{tabular}

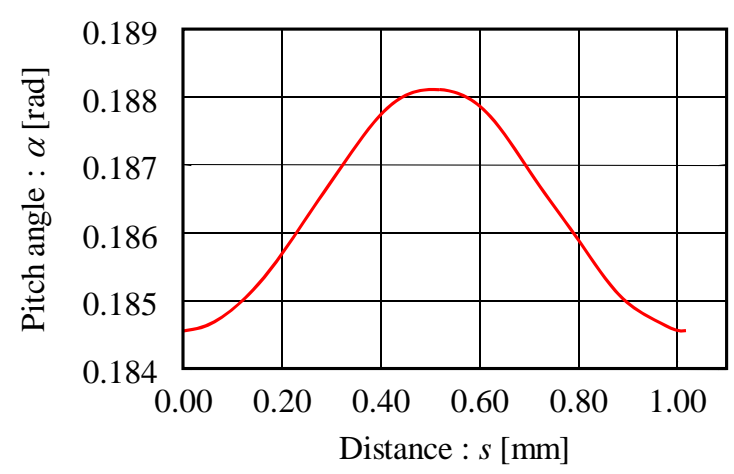

(a) Core wire

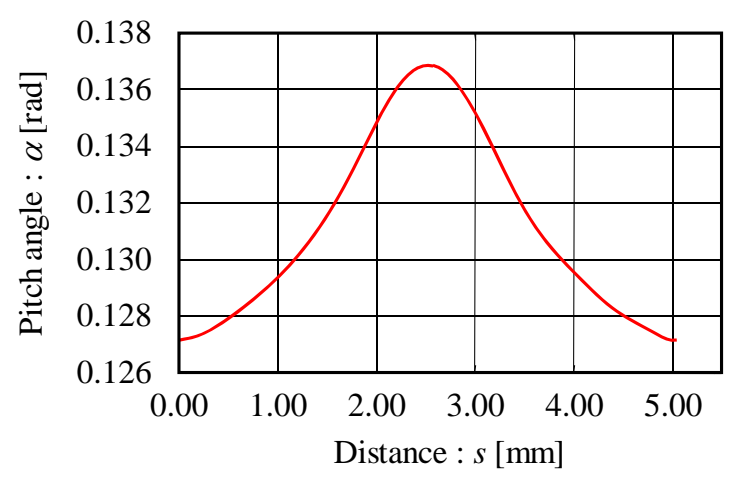

(b) Shielding wire

Fig. 4 Computational result of the pitch angle $\alpha$ of a core/shielding wire when a coaxial cable is bent. The pitch angle reaches to the maximum value at the point $\mathrm{P}(\mathrm{l} / 2)$ located on the inner periphery of the virtual toroid and to the minimum value at the points $\mathrm{P}(0)$ and $\mathrm{P}(l)$ located on the outer periphery of the virtual toroid. 


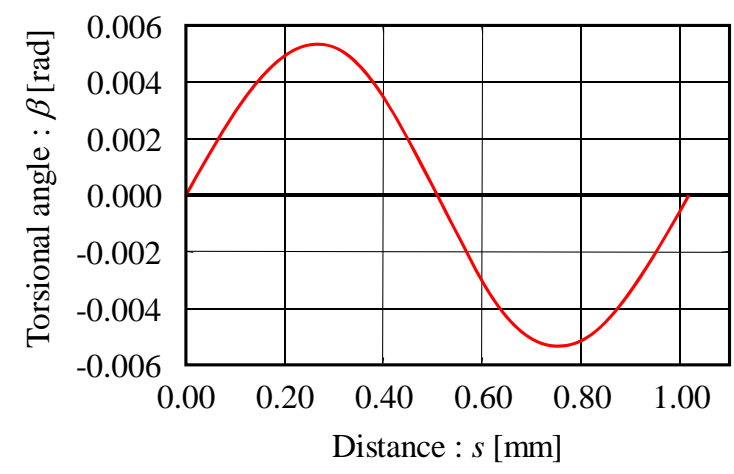

(a) Core wire

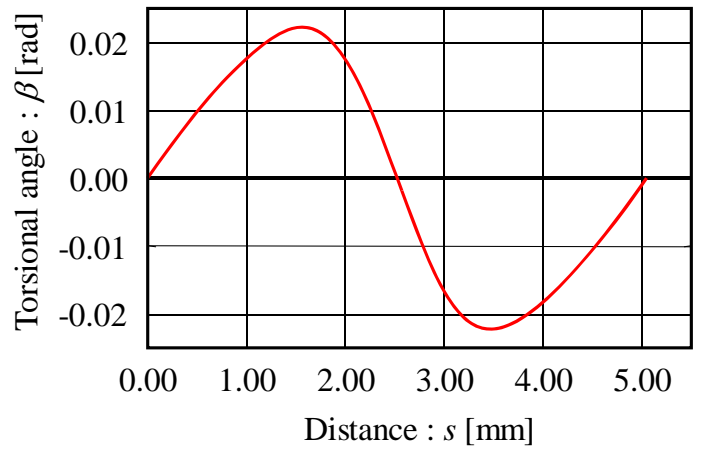

(b) Shielding wire

Fig. 5 Computational result of the torsional angle $\beta$ of a core/shielding wire when a coaxial cable is bent. The torsional angle is equal to zero at the points $\mathrm{P}(0), \mathrm{P}(l / 2)$ and $\mathrm{P}(l)$ located on the inner/outer periphery of the virtual toroid. In the outer side of the toroid, a strand is twisted in counterclockwise direction and it is twisted in clockwise direction in the inner side of the toroid.

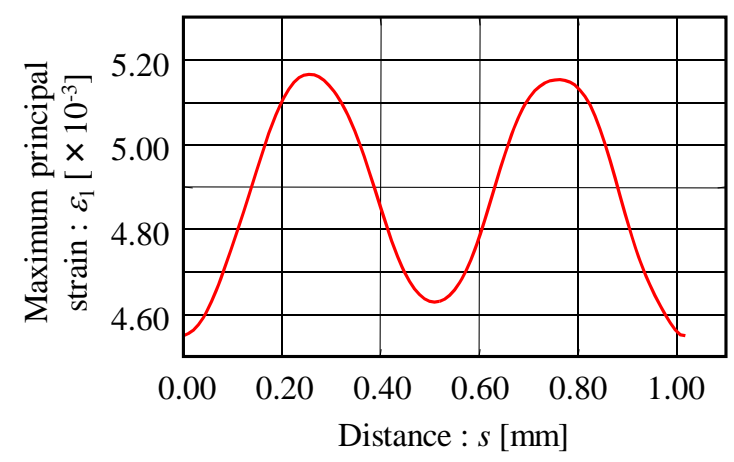

(a) Core wire

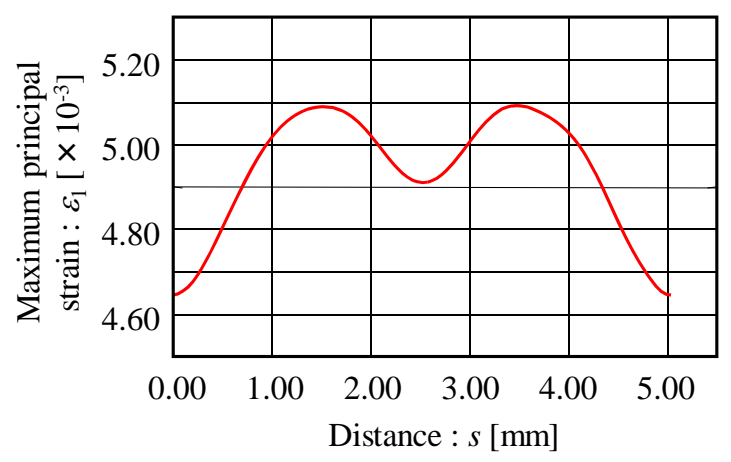

(b) Shielding wire

Fig. 6 Computational result of the maximum principal strain $\varepsilon_{1}$ of a core/shielding wire when a coaxial cable is bent. The profile of the maximum principal strain has two peaks and their values of the core wire are larger than those of the shielding wire. It indicates that the life-cycle of the core wire is shorter than that of the shielding wire if they have the same radius and rigidity.

図 7 に，摩擦はないものとし，伸び岡性 $R_{e}$ を変化させた場合の芯線およびシールド線の最大主ひずみ $\varepsilon_{1}(s)$ を 示す. 図 7 より, 芯線の場合, 伸び岡性 $R_{e}$ が小さくなる, すなわち伸縮しやすくなるにつれ，最大主ひずみが 小さくなる傾向にあることが分かる，一方，シールド線の場合には大きな変化は見られない．これは，芯線，シ 一ルド線共に垂直ひずみ $\varepsilon(s)$ は $10^{-5}$ オーダー， $\rho \Delta \kappa(s)$ および $\rho \Delta \omega_{\zeta}$ は $10^{-4}$ オーダーであるため, 式(33)より最大 主ひずみに対する曲率の変化量 $\Delta \kappa(s)$ およびねじれ率の変化量 $\Delta \omega_{\zeta}$ の影響度が高いのに加え，シールド線の場合 は，伸縮を考慮しても曲率の変化量 $\Delta \kappa(s)$ がほとんど変化しないためだと考えられる. 現実との整合性を考える と, 芯線が伸縮しやすい場合, Case C3 や Case C4 のように, 最大主ひずみがシールド線よりも全域で小さくなっ てしまうため，対象としている同軸ケーブルにおいては，芯線およびシールド線の伸縮はほとんど起こっていな いと予想される。

続いて，図 8 に，伸縮はないものとし，仮想ばねのばね定数 $k$ を変化させた場合の芯線およびシールド線の最 大主ひずみ $\varepsilon_{1}(s)$ を示す. 図 8 においても, 摩擦の影響はシールド線より芯線の方が大きく, ばね定数 $k$ が大きく なる，すなわち摩擦が大きくなると，芯線の最大主ひずみは小さくなっている．また，摩擦が大きい場合，芯線 の最大主ひずみがシールド線よりも全域で小さくなってしまうため, 現実との整合性から, 対象としている同軸 ケーブルにおいては，摩擦はほとんどないものと考えることができる. 
Ogai, Wakamatsu, Morinaga, Arai, Shimada and Manabe, Transactions of the JSME (in Japanese), Vol.80, No.814 (2014)

今回対象とした同軸ケーブルの場合には，実際の寿命や破断位置より，伸縮や摩擦はほとんど無視できると考 えられるが，本提案手法により，伸縮や摩擦を考慮した場合の素線束の最大主ひずみ分布への影響を考慮するこ とができる。

Table 2 The extensional rigidity and the virtual spring constant of core/shielding wire in each case

\begin{tabular}{|c|c|c|c|c|c|c|c|}
\hline Label for core wire & Case C1 & Case C2 & Case C3 & Case C4 & Case C5 & Case C6 & Case C7 \\
\hline Label for shielding wire & Case S1 & Case S2 & Case S3 & Case S4 & Case S5 & Case S6 & Case S7 \\
\hline $\begin{array}{l}\text { Ratio of the extensional rigidity to } \\
\text { the flexural rigidity }: R_{e} / R_{f}\end{array}$ & $\begin{array}{c}1.78 \times \\
10^{7}\end{array}$ & $\begin{array}{c}1.78 \times \\
10^{6}\end{array}$ & $\begin{array}{c}1.78 \times \\
10^{5}\end{array}$ & $\begin{array}{c}1.78 \times \\
10^{4}\end{array}$ & & 0.00 & \\
\hline $\begin{array}{l}\text { Ratio of the virtual spring constant } \\
\text { to the flexural rigidity : } k / R_{f}\end{array}$ & \multicolumn{4}{|c|}{0.00} & 0.00 & $\begin{array}{c}1.00 \times \\
10^{3}\end{array}$ & $\begin{array}{c}3.00 \times \\
10^{3}\end{array}$ \\
\hline
\end{tabular}

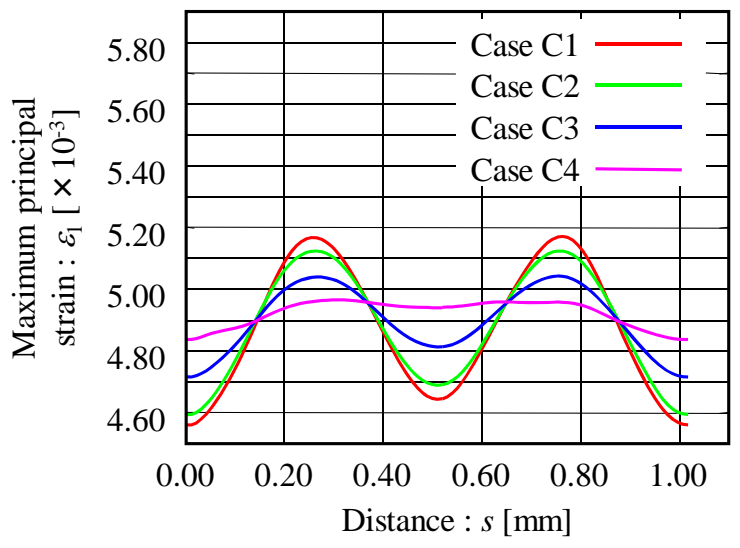

(a) Core wire

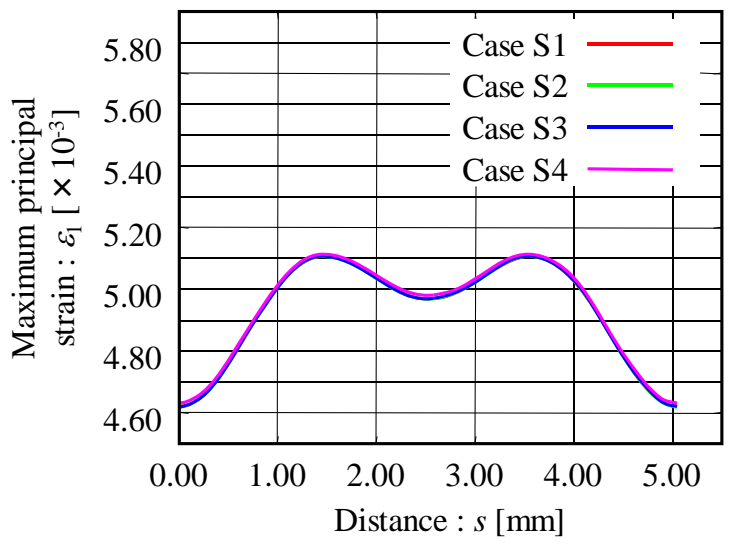

(b) Shielding wire

Fig. 7 Computational result of the maximum principal strain $\varepsilon_{1}$ of the core/shielding wire when its expansion/contraction is considered. Expansion/contraction affects the maximum principal strain of the core wire but has little effect on that of the shielding wire. If the extensional rigidity of the core wire is reduced, it might be possible to extend the life-cycle of the core wire.

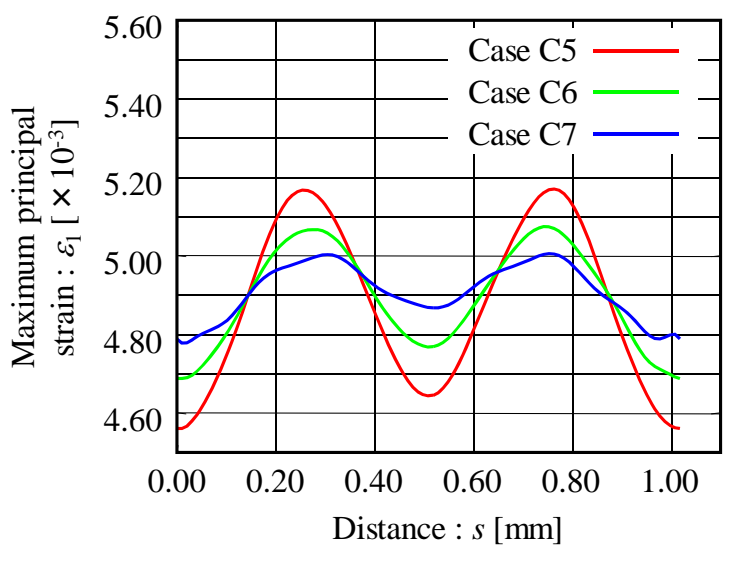

(a) Core wire

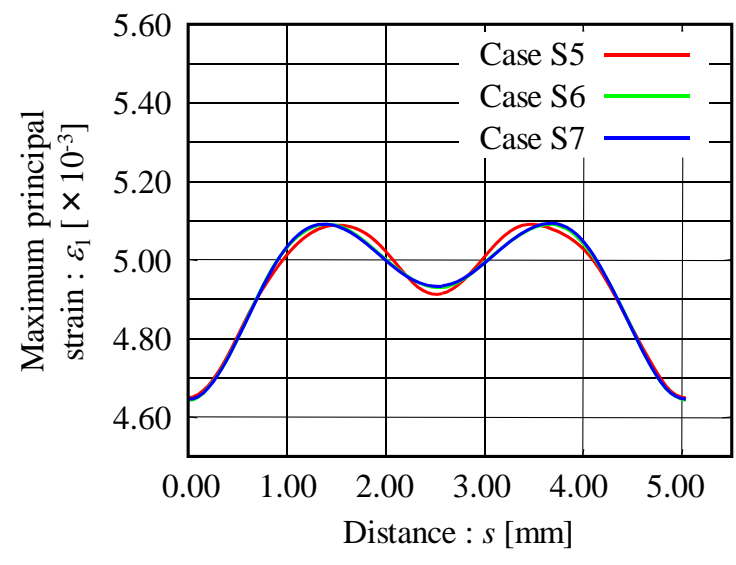

(b) Shielding wire

Fig. 8 Computational result of the maximum principal strain $\varepsilon_{1}$ of the core/shielding wire when its friction is considered. Friction affects the maximum principal strain of the core wire but has little effect on that of the shielding wire. If the position in the circumferential direction of the core wire is fixed, it might be possible to extend the life-cycle of the core wire. 


\section{5. 結}

本研究では，繰り返し曲げ変形を受ける同軸ケーブルの芯線およびシールド線の寿命を予測することを目的と して, 微分幾何学に基づき, それら素線束の変形形状および最大主ひずみの導出手法について提案した. 素線束 の形状は，伸縮を考慮しない場合は撚りピッチ角 $\alpha(s)$ とねじり角 $\beta(s)$ の 2 変数で，伸縮を考慮する場合には， 垂直ひずみ $\varepsilon(s)$ を加えた 3 変数で表現することができ, 素線束のポテンシャルエネルギーが最小となるような変 数を求めることにより，素線束の安定形状，さらには最大主ひずみ分布を推定することができる．素線束の寿命 は最大主ひずみより推定することができるため, 本提案手法により, 素線束の寿命を予測することが可能となる. 実際の同軸ケーブルを例に最大主ひずみを計算したところ，芯線の方がシールド線より最大主ひずみの最大值が 大きくなった，すわなち，芯線の方が寿命が短いと推定された点，また，最大主ひずみが最大となる屈曲部側面 において素線束が破断すると推定された点において，現実との整合性が見られたため，本提案手法による寿命推 定は妥当であると考えられる. 今後, 詳細な実験を行って, 本提案手法の妥当性について更なる検証を行ってい く予定である.

\section{謝 辞}

この研究は, 住友電気工業(株) との共同研究「電線の屈曲挙動解析技術の研究」により行われたものである. ここに謝意を表す.

\section{文献}

Boyer, F., Nayer, G. D., Leroyer, A. and Visonneau, M., Geometrically exact Kirchhoff beam theory: application to cable dynamics, Journal of Computational and Nonlinear Dynamics, Vol.6, No.4 (2011), 041004.

Elsgolc, L. E., Calculus of variations, Pergamon Press (1961), pp.144-157.

橋間正芳, 千田陽介, 佐藤祐一, ワイヤ・ハーネスの変形シミュレーションと設計支援システム, 情報処理学会論 文誌, Vol.48, No.2 (2007), pp.909-917.

Imanishi, E., Nanjo, T. and Kobayashi, T., Dynamic simulation of wire rope with contact, Journal of Mechanical Science and Technology, Vol.23, No.4 (2009), pp.1083-1088.

Jun, M.A., Ge, S. R. and Zhang, D. K., Distribution of wire deformation within strands of wire ropes, Journal of China

University of Mining and Technology, Vol.18, No.3 (2008), pp.475-478.

小林昭七，曲線と曲面の微分幾何，裳華房 (1995).

Lee, W. K., Helix geometry in wire rope, Wire Industry, Vol.54, No.644 (1987), pp.461-468.

Lee, W. K., An insight into wire rope geometry, International Journal of Solids Structures, Vol.28, No.4 (1991), pp.471-490.

小野進, ワイヤロープの微分幾何学的考察, 日本応用数理学会論文誌, Vol.3, No.4 (1993), pp.387-424.

小野進, 工学の数学 ーワイヤロープの微分幾何学一, アグネ技術センター (2005).

清水幹夫, 粒状要素法および有限要素法を用いた送電線の素線切れに関する数值解析的検討, 電力中央研究所報 告, 研究報告 U00061 (2001), pp.1-16.

鈴木克幸, 中住昭吾, 伊藤陽介, 正木剛, ケーブル運動のリアルタイムシミュレーション, 日本機械学会第18回計 算力学講演会講演論文集 (2005), pp.789-790.

\section{References}

Boyer, F., Nayer, G. D., Leroyer, A. and Visonneau, M., Geometrically exact Kirchhoff beam theory: application to cable dynamics, Journal of Computational and Nonlinear Dynamics, Vol.6, No.4 (2011), 041004.

Elsgolc, L. E., Calculus of variations, Pergamon Press (1961), pp.144-157.

Hashima, M., Senda, Y. and Sato, Y., Real-time simulation and design system for wire-harnesses, IPSJ Journal, Vol.48, No.2 (2007), pp.909-917 (in Japanese). 
Imanishi, E., Nanjo, T. and Kobayashi, T., Dynamic simulation of wire rope with contact, Journal of Mechanical Science and Technology, Vol.23, No.4 (2009), pp.1083-1088.

Jun, M.A., Ge, S. R. and Zhang, D. K., Distribution of wire deformation within strands of wire ropes, Journal of China University of Mining and Technology, Vol.18, No.3 (2008), pp.475-478.

Kobayashi, S., Differential geometry of curves and surfaces, Syokabo (1995) (in Japanese).

Lee, W. K., Helix Geometry in wire rope, Wire Industry, Vol.54, No.644 (1987), pp.461-468.

Lee, W. K., An insight into wire rope geometry, International Journal of Solids Structures, Vol.28, No.4 (1991), pp.471-490.

Ono, S., Approach to differential geometry in wire rope, Transactions of the Japan Society for Industrial and Applied Mathematics, Vol.3, No.4 (1993), pp.387-424 (in Japanese).

Ono, S., Mathematics of engineering -differential geometry of wire rope-, AGNE Gijutsu Center (2005) (in Japanese).

Shimizu, M., A numerical study on strand breakage of transmission line by means of granular element method and finite element method, Research Report of Central Research Institute of Electric Power Industry, No.U00061 (2001), pp.1-16 (in Japanese).

Suzuki, K., Nakasumi, S., Ito, Y. and Masaki, T., A real-time simulation for behavior of a cable, Proceedings of JSME Computational Mechanics Division Conference, Vol.2005, No.18 (2005), pp.789-790 (in Japanese). 